\title{
Salt Tolerance Study of Six Cultivars of Rice (Oryza sativa L.) During Germination and Early Seedling Growth
}

\author{
Majeed K Abbas ${ }^{1}$, Ali S Ali ${ }^{1}$, Hameed H Hasan ${ }^{2}$ \& Radhi H Ghal ${ }^{2}$ \\ ${ }^{1}$ College of Agriculture, Al-Qadisiya University, Iraq \\ ${ }^{2}$ State Board for Seed Testing and Certification in Diwaniya, Diwaniya, Iraq \\ Correspondence: Majeed $\mathrm{K}$ Abbas, College of Agriculture, Al-Qadisiya University, Iraq. Tel: \\ 964-0780-2344-057. E-mail: Majeed_edu@yahoo.com
}

Received: September 7, 2012 Accepted: September 27, 2012 Online Published: December 14, 2012

doi:10.5539/jas.v5n1p250

URL: http://dx.doi.org/10.5539/jas.v5n1p250

\begin{abstract}
Salinity is one of the major threats facing the cultivation of field crops. The response of six rice (Oryza sativus L.) cultivars to different sodium chloride levels; $0,30,60,90,120$, and $150 \mathrm{mM}$ were investigated during germination and early seedling stages. Germination percent, mean germination time (MGT), shoot and root length and dry weight were all decreased as the levels of $\mathrm{NaCl}$ used increased. Percent reduction in dry weight over control was increased as the $\mathrm{NaCl}$ levels increased. Forat and Amber 33 were more salt tolerant cultivars with regard to germination percent, while Hwazawi cultivar was more sensitive. Hwazawi cultivar recorded the lower MGT while Amber 33 cultivar showed the higher MGT. Length of radicle and plumule of all cultivars were differently affected by salt, as Hwazawi and Mushkab cultivars showed more reduction in length while Amber 33 was less affected. Forat cultivar dry weight was more affected by salt compare to other cultivars. The effect of $\mathrm{NaCl}$ on salt tolerance index of cultivars was significant. The ranges of salt tolerance indices among salt levels were very wide, ranging from 95.42 at $30 \mathrm{mM}$ of $\mathrm{NaCl}$ to 71.38 at $150 \mathrm{mM}$ of NaCl. Interaction between salt levels and cultivars showed varying degree of differences. It is concluded that the different cultivars differ in their salt tolerance with respect to seed germination and seedling growth.
\end{abstract}

Keywords: cultivars, rice, mean germination time, salt tolerance, response index, reduction in dry weight

\section{Introduction}

Rice is one of the world's most important staple crops that offer food for more than $50 \%$ of the world's population (Aggarwal et al., 2002). It is estimated that by the year 2025, the need to increase in rice production will be around $21 \%$ over the production of the year 2000 (Bhuiyan et al., 2002).

Salt stress undesirably affects plant growth during all developmental stages, therefore, it is a major threat to crop productivity. The response to salinity varies with growth stages, varieties/genotypes, and of salinization (Alam et al., 2004; Theerakulpisut et al., 2005; and Guan et al., 2010). Several investigators have stated that salt exerts negative effect on seed germination and seedling growth (Feizi et al., 2007; Azza et al., 2007; Abbad et al., 2004; Akbari et al., 2007).

Inhibition of seed germination and shoot and root was noticed as a result of sodium chloride treatments in rice and cabbage (Jamil et al., 2007; Sheng et al., 2011). Also, Razzaque et al. (2009) have found an adverse effect of salt on plant height, root, shoot and dry matter of seven rice genotypes. Salinity adverse effect on seed germination could be due either to osmotic effect or to ion toxicity (Huang \& Redmann, 1995; Ali et al., 2004).

Salt tolerance is known as the ability of the plant to survive and to complete its growth cycle under saline conditions (Seydi, 2003). Tolerance to salinity varies in accordance to stage of growth, adaptation characteristics of plant and species (Akbari et al., 2007). Zeng et al. (2002); and Akbari et al. (2007), have emphasized that salt tolerance could be differ between and within plant species. Several reliable criteria were used for selecting cultivars for rapid and uniform germination under saline conditions (Seydi, 2003; Bagci et al., 2003). The development of salt tolerant varieties has been considered as one of the strategies to increase rice production under saline conditions. The objectives of the present study were to evaluate salt tolerance of six rice cultivars during seed germination and seedling growth using some selected criteria. 


\section{Materials and Methods}

Seeds of six cultivars of rice namely; Amber 33, Yassimn, Forat, Sommod, Mushkab, and Hwazawi were used. The trial was conducted at the laboratory of College of Agriculture, Al-Qadisya University during June- July 2011. Seeds were surface-sterilized for $15 \mathrm{~min}$ in $10 \%(\mathrm{v} / \mathrm{v}) \mathrm{NaClO}$ and thoroughly washed with distilled water. Salt $(\mathrm{NaCl})$ concentrations used in the experiment were; $0,30,60,90,120$, and $150 \mathrm{mM}$. Ten seeds of rice were germinated in 9-cm Petri dishes containing double layered blotting paper and were treated with different concentrations of salt and kept at $25 \mathrm{c}$ under laboratory condition. One treatment was run as control with distilled water. Equal volume of distilled water was added in the dishes when moisture content of the blotting paper was declined. Seeds were considered as germinated when the radicle had protruded through the seed coat. Every one day germinated seeds were counted for every replication.

Germination percentage: Germination percentage was calculated after ten days of germination.

Mean germination time: Mean germination time (MGT) was calculated as follows:

$$
M G T=\frac{-\Sigma D n}{\sum n}(\text { days })
$$

Where; $\mathrm{n}$ is the number of seeds emerged on day $\mathrm{D}$, and $\mathrm{D}$ is the number of days counted from the beginning of emergence (Ellis \& Roberts, 1981).

Response Index (RI): RI was calculated at the end of germination according to Pellissier (1993) as follows: $\mathrm{RI}=($ test/control $)-1$

where test $=$ is the number of seeds germinated from test treatment

control=number of seeds germinated from control

If $-1<\mathrm{RI}>0$, the effect is inhibition; If $0<\mathrm{RI}>1$, effects is stimulation.

Shoot and root length $(\mathbf{c m})$ : Three weeks after planting, the shoot and root length were measured for each replication.

Shoot and root fresh and dry weight (g): The shoot and roots of plants in each replication were weighted fresh and then dried at 70c until a constant weight was reached.

Dry weight reduction over control (ROC): The inhibition effect on seedling dry weight induced by salinity was calculated in percent reduction over control (\% ROC) according to Ali et al. (2004).

$$
(\% \boldsymbol{R O C})=\frac{\text { Value in control }- \text { value in saline environment }}{\text { Value in control }} \times 100
$$

Salt tolerance index (STI): STI was calculated as total dry weight of plant obtained from different salt treatments concentrations compared to total plant dry weight obtained from control.

\section{$\mathbf{S T I}=(\mathrm{TDW}$ at $\mathrm{Sx} / \mathrm{TDW}$ at S1) $\times 100$}

Where; TDW=total dry weight, $S 1=$ control treatment, $S x=$ salt level treatment (Seydi, 2003).

Statistical analysis: The experiment was conducted in a completely randomized design (CRD) with four replications. The treatments means were compared by Least Significant Difference (LSD) test at 0.05 probability level (Steel \& Torrie, 1984).

\section{Results}

Final seed germination percentage was obviously decreased as the $\mathrm{NaCl}$ concentrations used increased (Figure 1). The inhibition of germination being strongest particularly at the higher concentrations of $\mathrm{NaCl}$ compare to control and lower concentrations. Also, the various cultivars show different response to salinity. Hwazawi cultivar was more sensitive to salinity as the final germination percent was just $56.88 \%$ compare to 93.55 and $93.44 \%$ for Forat and Amber 33, respectively. However, Amber 33, Forat, and Mushkab cultivars did not differ significantly from each other with regard to final germination percent and, therefore, are considered as salt tolerant cultivars. For the interaction between salt concentration and cultivars, it was clear that Hwazawi cultivar treated with 120 or 150 $\mathrm{mM}$ of Nacl gave the lowest percent of seed germination (26.66 and $20 \%$ respectively) followed by Yassmin treated with $150 \mathrm{mM}$ of $\mathrm{NaCl}$. 


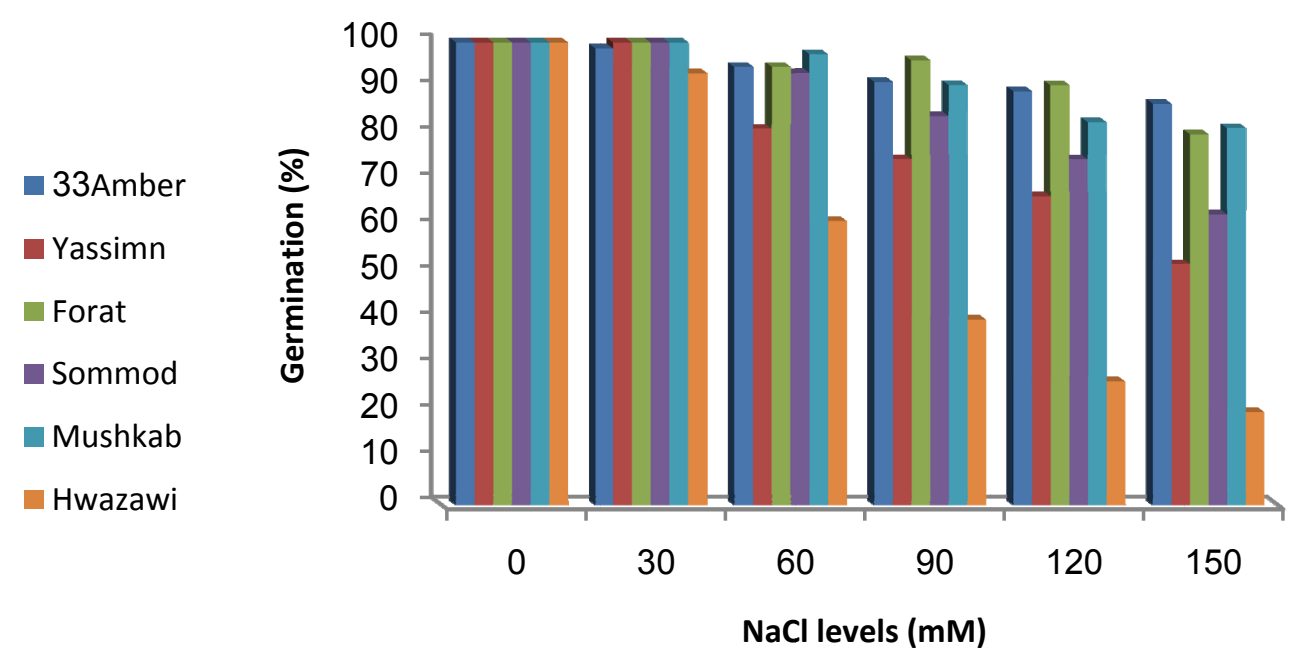

Figure 1. Effects of $\mathrm{NaCl}$ salinity on final germination percentage of six rice (Oryza sativa L.) cultivars

Mean germination time (MGT) is a measure of the germination velocity. It is known that the lower the MGT, the rapid the germination is. From our result, MGT was decreased as the concentration of the $\mathrm{NaCl}$ used increased (Figure 2). It was 2.73 at $150 \mathrm{mM}$ of $\mathrm{NaCl}$ compare to 6.02 for control. Hwazawi cultivar showed faster emergence as recorded the lower MGT (2.54) while Amber 33 cultivar showed the higher MGT (5.51). For the interaction, the maximum MGT was obtained for Sommod cultivar treated with $30 \mathrm{mM}$ of $\mathrm{NaCl}$ while the lower MGT was at Hwazawi cultivar treated with the highest concentration of $\mathrm{NaCl}$.

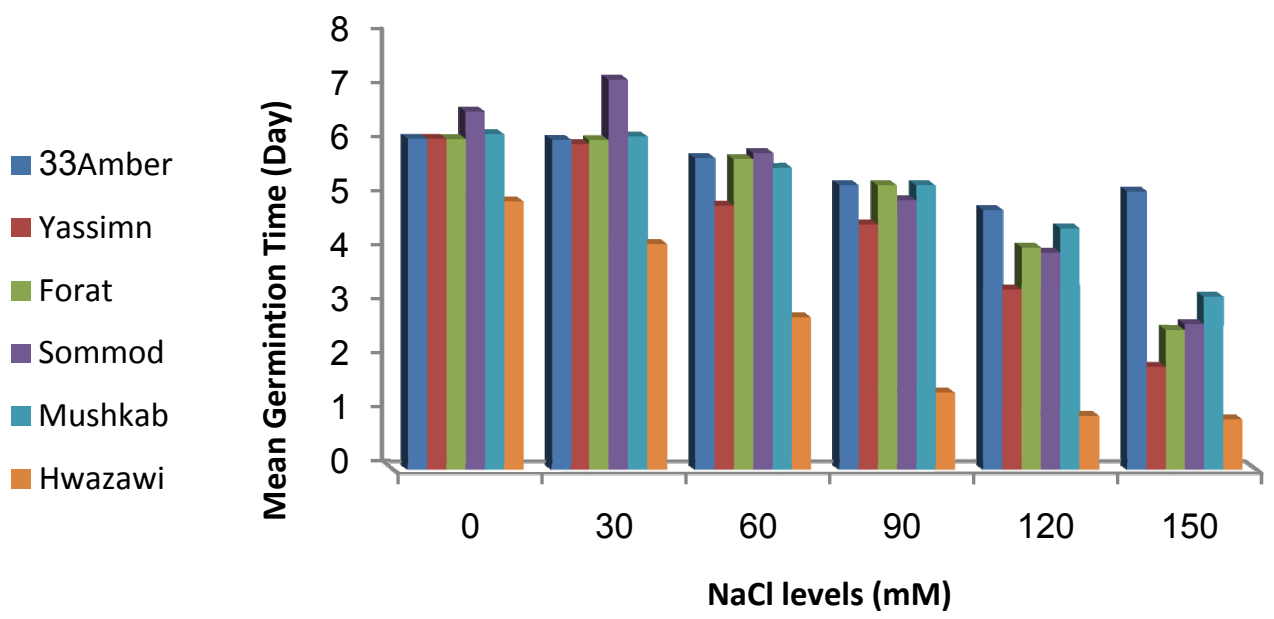

Figure 2. Effects of $\mathrm{NaCl}$ salinity on mean germination time (MGT) of six rice (Oryza sativa L.) cultivars

The obtained results of stress index show that the 120 and $150 \mathrm{mM}$ of $\mathrm{NaCl}$ are the most effective concentrations in suppressing germination of rice seeds (Table 1). Comparing among cultivars, Hwazawi show lower index while Amber 33 show the highest index. These results consistent with the results concerning germination percentage at which hwazawi cultivar show less percentage.

The results in figure 3 and 4 indicated that all $\mathrm{NaCl}$ concentrations caused retardation in radicle and plumule length. It was clear that as the concentration of $\mathrm{NaCl}$ increased, the length decreased dramatically. The magnitude of the decrease in radicle and plumule length at $150 \mathrm{mM}$ of $\mathrm{NaCl}$ was more than three fold in compare to control. Comparison among cultivars show that Hwazawi cultivar was more affected by salt with regard to radicle length 
followed by Sommod while Amber 33 and Forat were less effected. For plumule length, Mushkab cultivar was less tolerant to salt as showing less value while Amber 33 show the highest tolerant. For the interaction, it was clear that Amber 33 treated with 0 or $30 \mathrm{mM}$ of $\mathrm{NaCl}$ show higher values for shoot and root length while Hwazawi treated with $150 \mathrm{mM}$ of $\mathrm{NaCl}$ gave the lower value for root length and Mushkab treated with the same level of $\mathrm{NaCl}$ gave the lower value of shoot length.

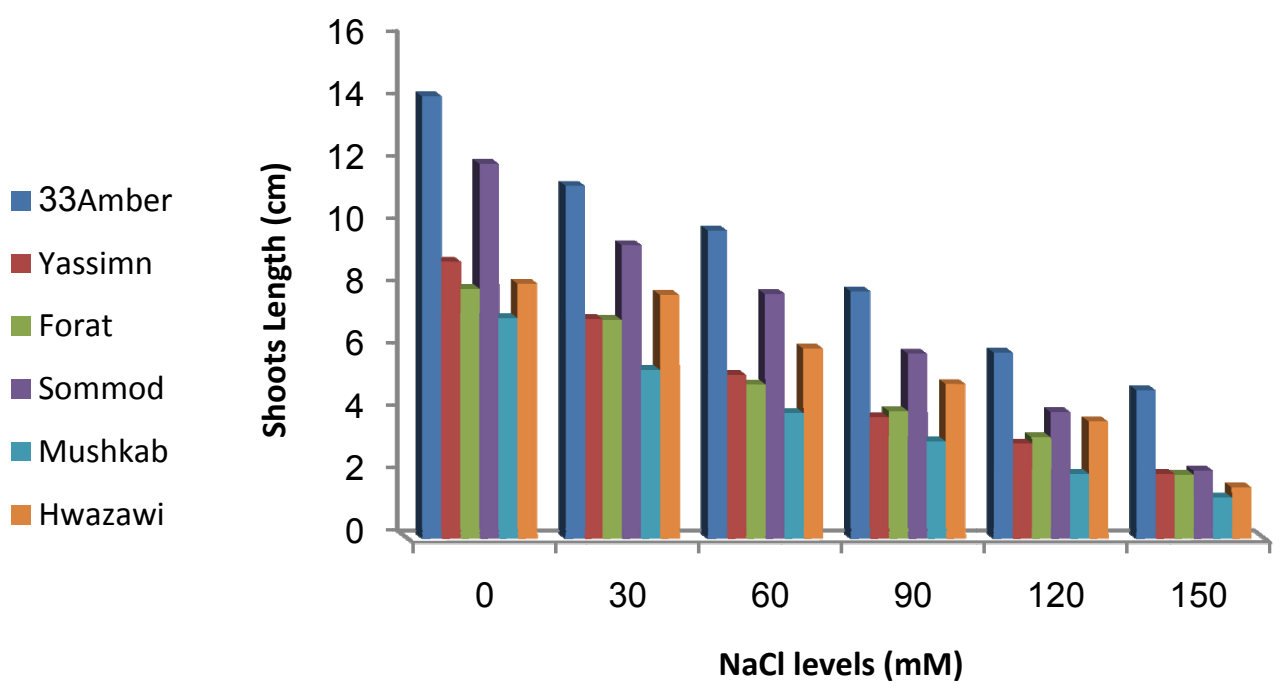

Figure 3. Effects of $\mathrm{NaCl}$ salinity on shoot length $(\mathrm{cm})$ of six rice (Oryza sativa L.) cultivars

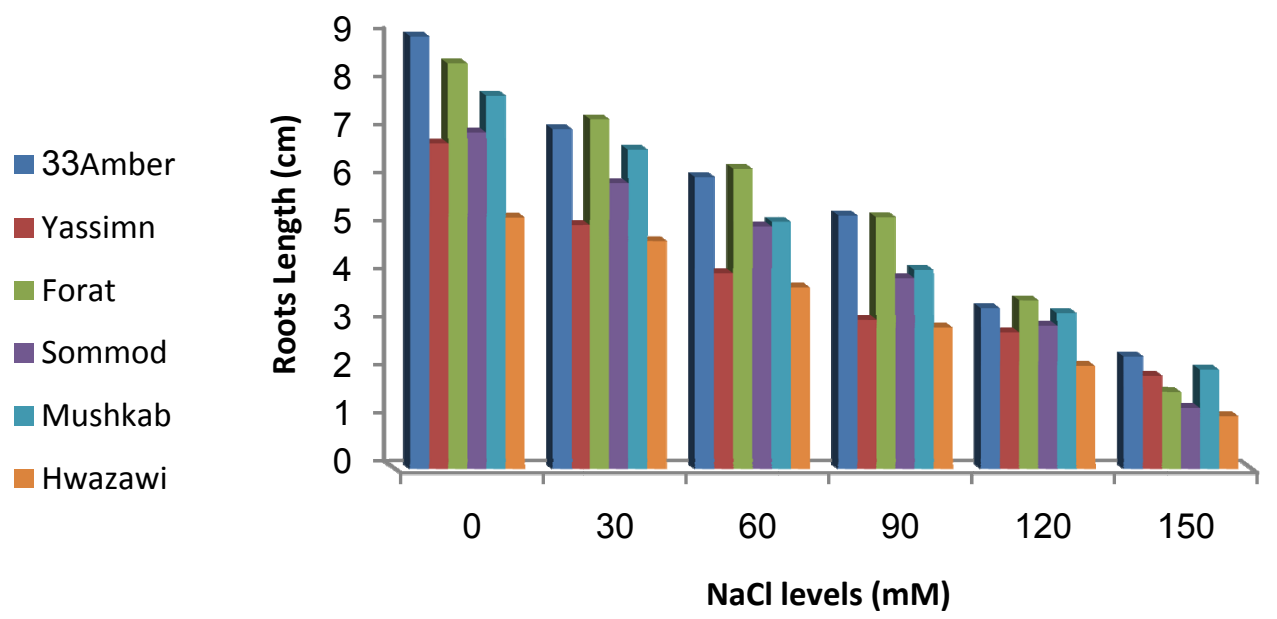

Figure 4. Effects of $\mathrm{NaCl}$ salinity on root length $(\mathrm{cm})$ of six rice (Oryza sativa L.) cultivars

Results of whole seedling, radicle and plumule dry weight show same trend of reduction with increasing salinity as that for other parameters measured (Figure 5,6 and 7). Forat cultivar show more reduction in dry weight while Amber33 show less reduction compare to other cultivars.

Percent reduction over control results (Table 1) show that as the levels of $\mathrm{NaCl}$ increased the reduction in dry weight increased also. The $150 \mathrm{mM}$ of $\mathrm{NaCl}$ gave the highest reduction $(28.62 \%)$ followed by $120 \mathrm{mM} \mathrm{of} \mathrm{NaCl}$ $(22.23 \%)$. However, the six cultivars show no differences among them. 
Table 1. Effects of $\mathrm{NaCl}$ salinity on percent reduction over control (\%) of six rice (Oryza sativa L.) cultivars

\begin{tabular}{lllllll}
\hline \multicolumn{7}{c}{ Levels of NaCl salinity $(\mathrm{mM})$} \\
\hline Cultivars & 30 & 60 & 90 & 120 & 150 & Mean \\
Amber 33 & 6.30 & 9.30 & 14.77 & 22.39 & 29.28 & 16.40 \\
Yassmin & 5.23 & 10.46 & 14.95 & 21.96 & 29.28 & 16.37 \\
Forat & 4.02 & 10.54 & 15.97 & 23.58 & 30.43 & 16.70 \\
Sommod & 3.86 & 9.65 & 15.05 & 19.88 & 26.64 & 15.01 \\
Mushkab & 3.88 & 10.17 & 16.05 & 23.39 & 28.64 & 16.42 \\
Hwazawi & 4.22 & 11,94 & 17.23 & 22.19 & 27.48 & 16.61 \\
Mean & 4.58 & 10.34 & 15.67 & 22.23 & 28.62 & \\
LSD 5\% & For NaCl levels=5.66 & For cultivars=N.S & For interaction=9.85 \\
\hline
\end{tabular}

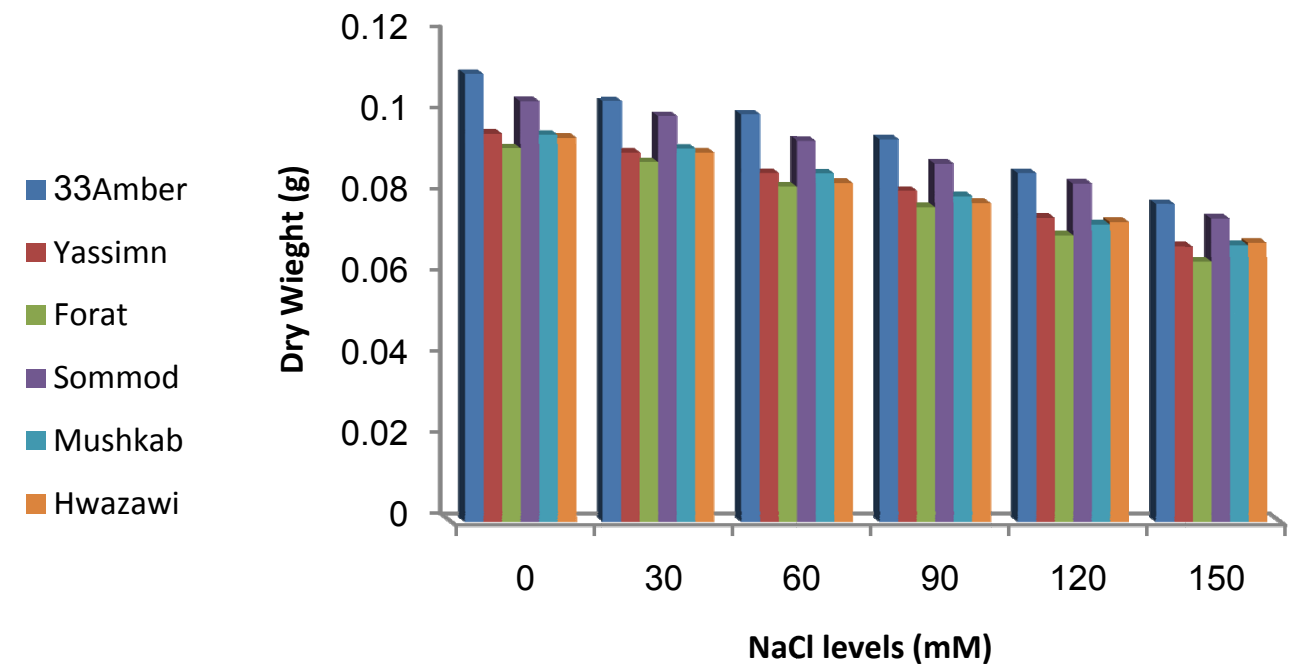

Figure 5. Effects of $\mathrm{NaCl}$ salinity on total dry weight of whole seedling (g) of six rice (Oryza sativa L.) cultivars

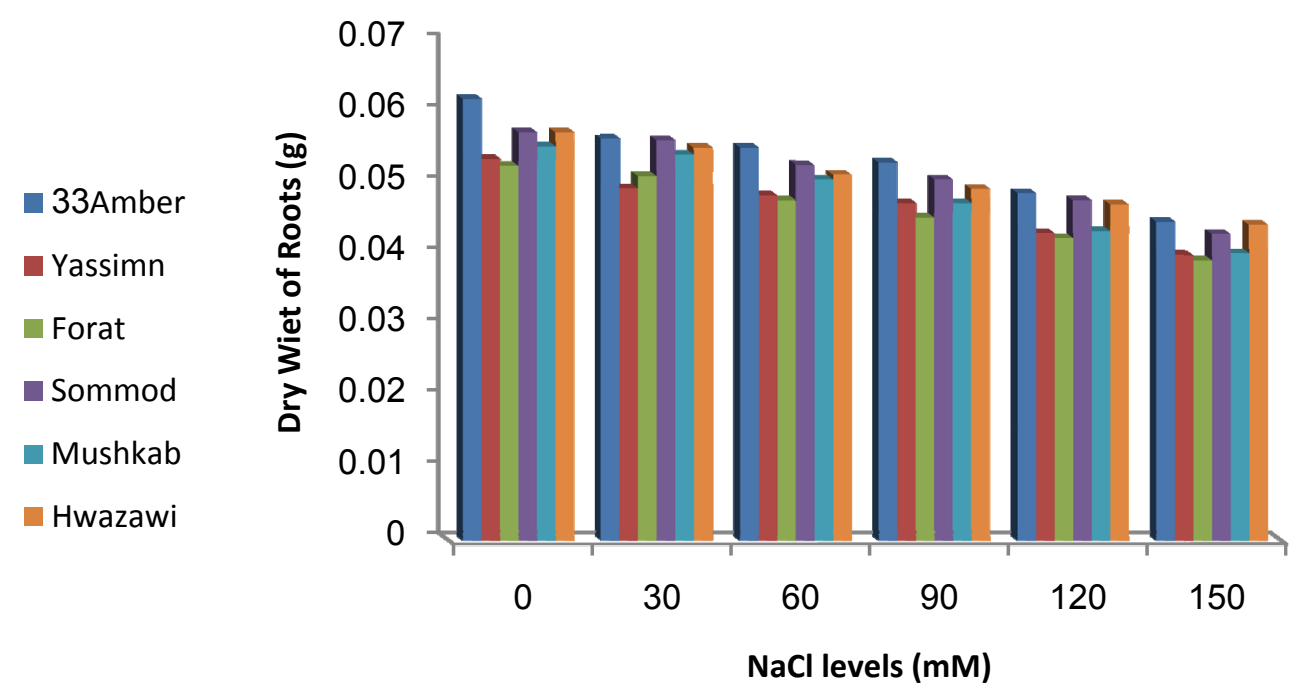

Figure 6. Effects of $\mathrm{NaCl}$ salinity on dry weight of roots (g) of six rice (Oryza sativa $\mathrm{L}$.) cultivars 


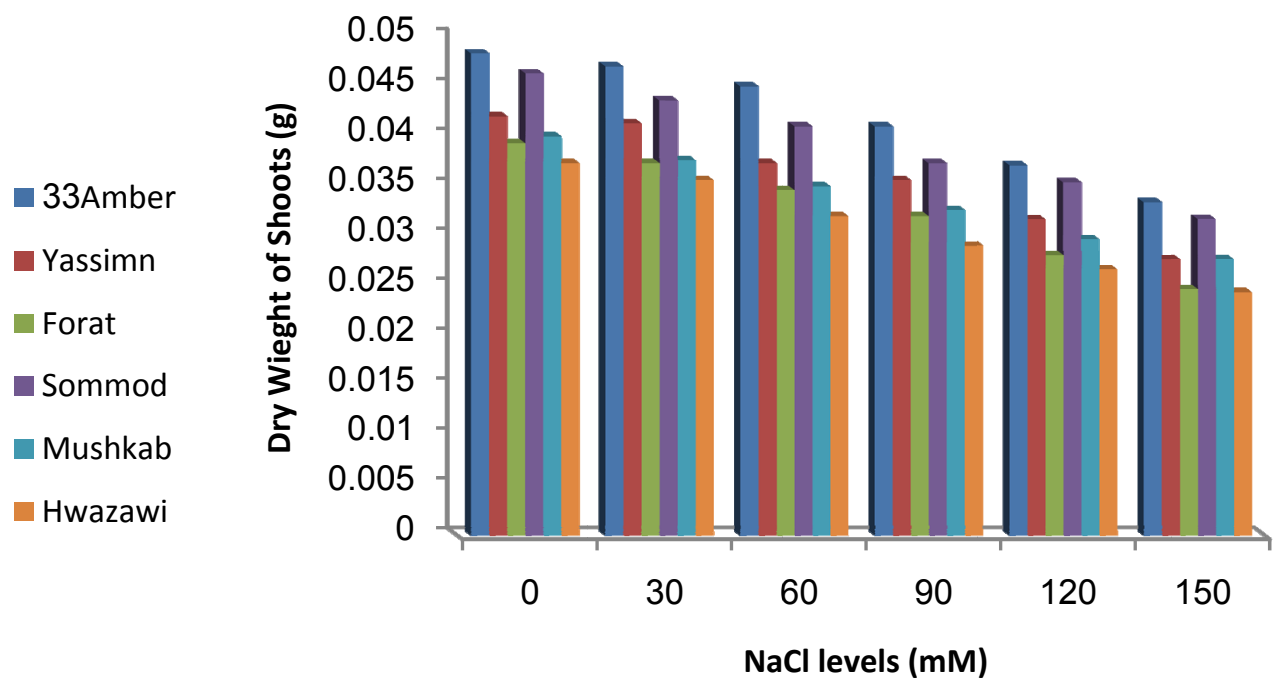

Figure 7. Effects of $\mathrm{NaCl}$ salinity on dry weight of shoot (g) of six rice (Oryza sativa L.) cultivars

From the current result it seems that the effect of $\mathrm{NaCl}$ on salt tolerance index of cultivars was significant (Figure 8). The ranges of salt tolerance indices among concentrations were very wide ranging from 95.42 at $30 \mathrm{mM}$ of $\mathrm{NaCl}$ to 71.38 at $150 \mathrm{mM}$ of $\mathrm{NaCl}$. However, the various cultivars show no differences in the index. The interaction effects of salinity and cultivars were significant for all trials. The highest salt tolerance indices were recorded for Forat, Sommod and Mushakb cultivars treated with 30mM (96.01-96.0). The lowest index was at Amber33 and Yassimn treaed with $150 \mathrm{mM}$.

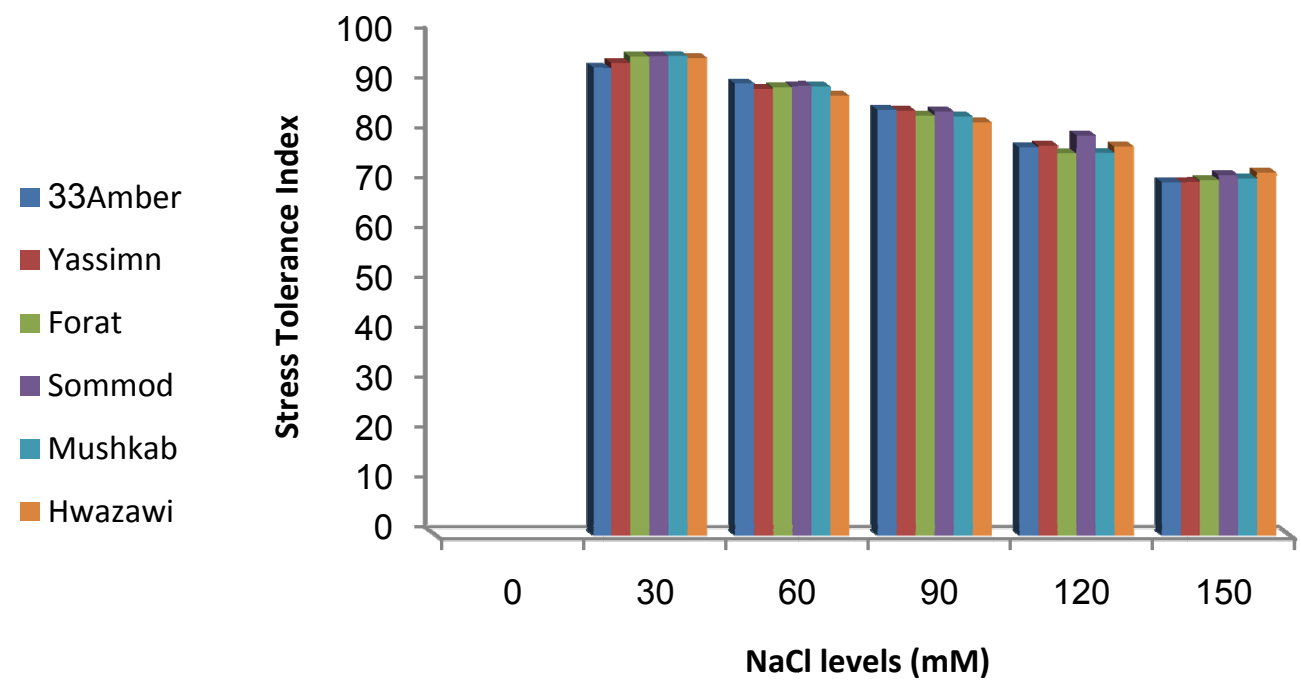

Figure 8. Effects of $\mathrm{NaCl}$ salinity on salt tolerance index (STI) of six rice (Oryza sativa $\mathrm{L}$.) cultivars

\section{Discussion}

The current results clearly show that $\mathrm{NaCl}$ decreased seed germination in proportion to increase its concentration. This result is in agreement with the results of Xue et al. (2004); Jamil et al. (2007); and Akbari et al. (2007). It has been reported that increasing salinity concentration at germination stage often cause osmotic effect which lead to decreasing the rate of water uptake and/ or specific ion toxicity and as a result, may reduce germination percent (Huang \& Redmann, 1995). Azza et al. (2007) emphasizes that the mechanism of inhibition of germination and seedling growth by $\mathrm{NaCl}$, maybe related to insufficient water absorption, or to toxic effects on the embryo. 
Al-Ahmadi and Kafi (2006) found that germination percentage had an inverse relation with salinity. Also, there is a varietal difference in response to salinity. The interaction between salt concentration and cultivars emphasize that variation. Hasegawa et al. (2000) have stated that salt stress and tolerance in several species including rice might include the expression of specific genes and repress or completely suppress the expression of others. Our results are consistent with previous ones which show that different genotypes of barley having different responses to increasing salt levels (Mano \& Takeda, 1997). Also, Guan et al. (2010), mentioned that Suaeda species varied in their salt stress tolerance with regard to germination rates.

Results regarding mean germination time come in agreement with the result of Abaril et al. (2011), who they found that increasing $\mathrm{NaCl}$ concentrations in germination media resulted in decreased germination percentage and speed of $A$. oerfota and A. tortilis. However, the current results disagree with the findings of Jeannette et al. (2002) who they found that MGT of some species of Phaseolus increased as the $\mathrm{NaCl}$ concentrations used increased, and also the results of Al-Ahmadi and Kafi (2006) who stated that salinity increased the time required to $50 \%$ germination of Kochia plant.

Results of stress index show that the higher concentrations of $\mathrm{NaCl}$ were the most effective concentrations in reducing germination of rice (Table 2). However, lower response index values reflect a more potent inhibitory activity (Lungu et al., 2011). The retardation of the radicle growth under salt stress may be due to the reduction in the turgor of the radicle cells (Bewley \&tions of $\mathrm{NaCl}$ reduced radicle and hypocotyls length. Also, Jamil et al. (2007), mentioned that using $\mathrm{NaCl}$ at concentrations between 4.7 to $14.1 \mathrm{dSm}^{-1}$ inhibited seed germination and seedling growth of two varieties of cabbage.

Table 2. Effects of $\mathrm{NaCl}$ salinity on stress index (SI) of six rice (Oryza sativa $\mathrm{L}$.) cultivars

\begin{tabular}{lcccccc}
\hline \multicolumn{7}{c}{ Levels of $\mathrm{NaCl}$ salinity $(\mathrm{mM})$} \\
\hline Cultivars & 30 & 60 & 90 & 120 & 150 & Mean \\
Amber33 & 0.0300 & $-0.0300^{*}$ & -0.2500 & -0.5366 & -0.5200 & -0.2177 \\
Yassmin & -0.1400 & -0.1933 & -0.2333 & -0.7666 & -0.8533 & -0.3644 \\
Forat & -0.0133 & -0.0500 & -0.5400 & -0.8233 & -1.000 & -0.4044 \\
Sommod & 0.0133 & -0.0866 & -0.1866 & -0.5500 & -1.000 & -0.3016 \\
Mushkab & -0.040 & -0.3733 & -0.3500 & -0.6400 & -0.8800 & -0.3805 \\
Hwazawi & -0.6666 & -0.8000 & -0.8666 & -1.000 & -1.000 & -0.7222 \\
Mean & -0.1361 & -0.2555 & -0.4044 & -0.7194 & -0.8755 & \\
LSD 5\% & For NaCl levels $=0.0732$ & For cultivars=0.0732 For interaction=0.1755 & \\
\hline
\end{tabular}

* the (-) sign means inhibition effect.

High concentrations of $\mathrm{NaCl}$ show strong inhibition of germination and root and shoot length in compare to lower concentrations. Similar results have been reported by Young et al. (2005) and Zhao et al. (2009). Also, the current results revealed a pronounced genotypic differences with regard to radical and plumule length. Suplick-Ploense et al., 2002, stated that tolerant cultivars of bluegrass showed less growth reduction than sensitive genotypes under salinized conditions. Also, Theerakulpisut et al., 2005, mentioned that the magnitude of changes in some physiological parameters were different among different cultivars and were related to the level of salinity.

Dry weight of whole seedling, radicle and plumule were all reduced with increasing salinity same as that for other parameters measured (Figure 5, 6 and 7). This result comes in consistent with previous ones (Romero-Aranda et al., 2001; Carpic et al., 2010). Theerakulpisut et al., 2005 stated that the weight of shoots and roots showed high correlation with the level of salinity. Ashraf, 2002, mentioned that the reduction in seedling fresh and dry weight is due to decreasing water uptake by seedlings in salt stress presence. Forat cultivar show more reduction in dry weight while Amber33 show less reduction compare to other cultivars. Soubir et al., 2009, found a large variation in salinity tolerance among different rice germplasms. They stated that salt stress of $12 \mathrm{dSm}^{-1}$ reduced seedling total dry matter by $40.6 \%$ of tolerant lines and by $46.0-73.5 \%$ for susceptible lines. Similar results were reported for corn (Rahman et al., 2000) and rice (Zhang et al., 2004) at which relative salt sensitivity and tolerance differ among different cultivars. 
Salt tolerance index, which is a function of total dry weight, is considered to be a reliable criterion for salt tolerance (Seydi, 2003; Bagci et al., 2003). It was clear from our findings that salt tolerance index of all cultivars is clearly effected by $\mathrm{NaCl}$ concentrations. This result agrees with the result of (Carpici et al, 2010). Al-Thabet et al. (2004) stated that plant growth inhibition is a common response to salinity and plant growth is one of the most important agricultural indices of salt stress tolerance. In addition, Ali et al., 2004 mentioned that the reduction in leaf area, and as a result dry weight, of 18 rice genotypes under salinity stress plants has been attributed to suppressed cell division.

\section{Conclusion}

It was obvious that increasing levels of $\mathrm{NaCl}$ reduced germination percentage, shoot and root length and dry weight. Amber33 was the most salt tolerant cultivar while Hwazawi was the least tolerant among the tested cultivars. Therefore, it is recommended for the Iraqi farmers to cultivate the former cultivar in salty soil. Criteria such as response index and salt tolerance index are proved to be a good and reliable measure of salt tolerance.

\section{References}

Abari1, A. K., Mohammad, H. N., Mohammad, H., \& Dariush, B. (2011). Salt effects on seed germination and seedling emergence of two Acacia species. African J Plant Sci., 5(1), 52-56.

Abbad, A., El Hadrami, A., \& Benchabane, A. (2004). Germination responses of the Mediterranean saltbush (Atriplex halimus L.) to $\mathrm{NaCl}$ treatment. J. Agron., 3(2), 111-114. http://dx.doi.org/10.3923/ja.2004.111.114

Aggarwal, R. K., Shenoy, V. V., Ramadevi, J., Rajkumar, R., \& Singh, L. (2002). Molecular characterization of some Indian basmati and other elite rice genotypes using fluorescent AFLP. Theor. Appl. Gent., 105, 680-690. http://dx.doi.org/10.1007/s00122-002-0973-6

Akbari, G., S., Mohammad, A., \& Yousefzadeh, S. (2007). Effect of auxin and salt stress (NaCl) on seed germination of wheat cultivars (Triticum aestivum L.). Pakistan J. Biol. Sci., 10(15), 2557-2561. http://dx.doi.org/10.3923/pjbs.2007.2557.2561

Al-Ahmadi, M. J., \& Kafi, M. (2006). Salinity effects on germination properties of Kochia scoparia. Asian J. Plant Sci., 5(1), 71-75. http://dx.doi.org/10.3923/ajps.2006.71.75

Alam, M. Z., Stuchbury, T., Naylor, R. E. L., \& Rashid, M. A. (2004). Effect of salinity on growth of some modern rice cultivars. J. Agronomy, 3(1), 1-10. http://dx.doi.org/10.3923/ja.2004.1.10

Ali, Y., Aslam, Z., Ashraf, M. Y., \& Tahir, G. R. (2004). Effect of salinity on chlorophyll concentration, leaf area, yield and yield components of rice genotypes grown under saline environment. Intern. J. Envir. Sci. Technol., 1(3), 221-225.

Al-Thabet, S. S., Leilah, A. A., \& Al-Hawass, I. (2004). Effects of $\mathrm{NaCl}$ and incubation temperature on seed germination of three canola (Brassica napus L.) cultivars. Sci. J. King. Faisel. Univer., 5(1), 81-91.

Ashraf, M. (2002). Evaluation of genetic variation for improvement of salt tolerance in spring wheat. In R. Ahmed, \& K. A. Malik (Eds.), Prospects for Saline Agriculture (pp. 131-137). Netherlands, Kluwer Academic Publisher.

Azza, M. A. M., Fatma EL-Quensi, E. M., \& Farahat, M. M. (2007). Responses of ornamental plants and woody trees to salinity. World J. Agric. Sci., 3(3), 386-395.

Bagci, S. A., Ekiz, H., \& Y1lmaz, A. (2003). Determination of the salt tolerance of some barley genotypes and the characteristics affecting tolerance. Turk. J. Agric. For., 27, 253-260.

Bewley, J. D., \& Black, M. (1994). Seeds: Physiology of Development and Germination (2 ${ }^{\text {nd }}$ ed.) (pp. 147). New York and London: Plenum Press.

Bhuiyan, N. I., Paul, D. N. R., \& Jabber, M. A. (2002). Feeding the extra millions by 2025: challenges for rice research and extension in Bangladesh. In Proceedings of the National Workshop on Rice Research and Extension. Bangladesh Rice Research Institute, Gazipur, January 29-31.

Carpici, E. B., Necmettin, C., Gamz B., \& Bulen, B. A. (2010).The effects of salt stress on the growth, biochemical parameter and mineral element content of some maize (Zea mays L.) cultivars. African J. Biotech., 9(41), 6937-6942.

Ellis, R. A., \& Roberts, E. H. (1981). The quantification of ageing and survival in orthodox seeds. Seed Sci Technol., 9, 373-409. 
Feizi, M., Aghakhani, A., Mostafazadeh-Frad, B., \& Heidarpour, M. (2007). Salt tolerance of wheat according to soil and drainage water salinity. Pakistan J. Biol. Sci., 10(17), 2824-2830. http://dx.doi.org/10.3923/pjbs.2007.2824.2830

Guan, B., Yu, J., Lu, Z., Japhet, W., Chen, X., \& Xie, W. (2010). Salt tolerance in two Suaeda species: seed germination and physiological response. Asian J. Plant Sci., 9(4), 194-199. http://dx.doi.org/10.3923/ajps.2010.194.199

Hasegawa, P. M., Bressan, R. A., Zhu, J. K., \& Bonhert, H. J. (2000). Plant cellular and molecular responses to high salinity. Annu. Rev. Plant Physio. Plant Mol. Biol., 51, 463-499. http://dx.doi.org/10.1146/annurev.arplant.51.1.463

Huang, J., \& Redmann, R. E. (1995). Salt tolerance of Hordeum and Brassica species during germination and early seedling growth. Can. J. Plant Sci., 75, 815-817. http://dx.doi.org/10.4141/cjps95-137

Jamil, M., Lee, K. B., Jung, K. Y., Lee, D. B., Han, M. S., \& Rha, E. S. (2007). Salt stress inhibits germination and early seedling growth in cabbage (Brassica oleracea capitata L.). Pakistan J. Biol. Sci., 10(6), 910-914. http://dx.doi.org/10.3923/pjbs.2007.910.914

Jeannette, S., Craig, R., \& Lynch, J. P. (2002). Salinity tolerance of phaseolus species during germination and early seedling growth. Crop Sci., 42, 1584-1594. http://dx.doi.org/10.2135/cropsci2002.1584

Lungu, L, Popa, C., Morris, J., \& Savoiu, M. (2011). Evaluation of phytotoxic activity of Melia azedarach L. extracts on Lactuca sativa L. Romanian Biotech. Letters, 16(2), 6089- 6095.

Mano, Y., \& Takeda, K. (1997). Diallel analysis of salt tolerance at germination and the seedling stage in barley (Hordeum vulgare L.). Breeding Sci., 47, 203-209.

Pellisser, F. (1993). Allelopathic inhibition of spruce germination. Acta Oecol., 14 (2), 211-218.

Rahman, M., Kayani, S. A., \& Gul, S. (2000). Combined effects of temperature and salinity stress on corn cv. Sunahry, Pak. J. Biological Sci., 3(9), 1459-1463. http://dx.doi.org/10.3923/pjbs.2000.1459.1463

Razzaque, M. A., Talukder, N. M., Islam, M. S., Bhadra, A. K., Dutta, R. K. (2009). The effect of salinity on morphological characteristics of seven rice (Oryza sativa) genotypes differing in salt tolerance. Pakistan J. Biol. Sci., 12(5), 406-412. http://dx.doi.org/10.3923/pjbs.2009.406.412

Romero Aranda, R., Soria, T., \& Cuartero, S. (2001). Tomato plant-water uptake relationships under saline growth conditions. Plant Sci., 160, 265-272. http://dx.doi.org/10.1016/S0168-9452(00)00388-5

Seydi, A. B. (2003). Determination of the salt tolerance of some barley genotypes and the characteristics affecting tolerance. Turk J. Agric., 27, 253-260.

Sheng, X., Hu, B., He, Z., Ma, F., Feng, J., Shen, W., \& Yang, J. (2011). Enhancement of salinity tolerance during rice seed germination by presoaking with hemoglobin. Int. J. Mol. Sci., 12, 2488-2501. http://dx.doi.org/10.3390/ijms12042488

Soubir, T., Salil, K. B., Mirza, M. I., Ayesha, S., Sharmin, S., \& Shahidul, L. (2009). Phenotypic and genotypic screening of rice genotypes at seedling stage for salt tolerance. Revista UDO Agricola, 9(4), 770-775.

Steel, R. G. D., \& Torrie, J. H. (1984). Principles and Procedures of Statistics. A Bionetrical Approach (2nd ed.) (pp. 172-177). Singapoe: McGraw Hill Book Co. Inc.

Suplick Ploense, M. R., Qian, Y. L., \& Read, J. C. (2002). Salinity tolerance of Texas bluegrass, Kentucky bluegrass, and their hybrids. Crop Sci., 42, 2025-2030. http://dx.doi.org/10.2135/cropsci2002.2025

Theerakulpisut, P., Bunnag S., \& kong-Ngern, K. (2005). Genetic diversity, salinity tolerance and physiological responses to $\mathrm{NaCl}$ of six rice (Oryza sativa L.) cultivars. Asian J. Plant Sci., 4(6), 562-573. http://dx.doi.org/10.3923/ajps.2005.562.573

Xue, Z., Zhi, D., Xue, G., Zhang, H., Zhao, Y., \& Xia, G. (2004). Enhanced salt tolerance of transgenic wheat ( Triticum aestivum L.) expressing a vacuolar $\mathrm{Na}^{+} / \mathrm{H}^{+}$antiporter gene with improved grain yields in saline soils in the fioed an a reduced level of leaf $\mathrm{Na}^{+}$. Plant Sci., 167, 849-859. http://dx.doi.org/10.1016/j.plantsci.2004.05.034

Young, G. S., Lee, B. H., Kang, K. Y., \& Lee, 1. J. (2005). Effects of Nacl stress on germination, antioxidant responses, and proline content in two rice cultivars. J. Plant Biol., 48(2), 201-208. http://dx.doi.org/10.1007/BF03030409 
Zeng, L., Shannon, M. C., \& Grieve, C. M. (2002). Evaluation of salt tolerance in rice genotypes by multiple agronomic parameters. Euphytica, 127, 235-245. http://dx.doi.org/10.1023/A:1020262932277

Zhang, Z. H., Li, P., Wang, L. X., Hu, Z. L., Zhu, L. H., \& Zhu, Y. G. (2004). Genetic dissection of the relationships of biomass production and partitioning with yield and yield related traits in rice. Plant Sci., 167, 1-8. http://dx.doi.org/10.1016/j.plantsci.2004.01.007

Zhao, X., Tan, H. J., Liu, Y. B., Li, X. R., \& Chen, G. X. (2009). Effect of salt stress on growth and osmotic regulation in Thellungiella and Arabidopsis callus. Plant Cell Tissue Organ Cult., 98, 97-103. http://dx.doi.org/10.1007/s1 1240-009-9542-x 